\title{
Review of Status of Tribal Women in Tripura by Malbika Das Gupta
}

\author{
Tasadoq Hussain Jaweed ${ }^{1 *}$ and Nilofer Khan ${ }^{2}$
}

\author{
Book details \\ Gupta, MD (eds) \\ Status of Tribal Women in Tripura. \\ Vikas Publishing House Pvt Ltd New Delhi; 1993. \\ Xii+79 pages, ISBN 0-7069-7352-6
}

Keywords: Bride price; Decision making; Economic participation; Sati; Tribal women

Women play a central role in the pastoral way of life, providing labour for the livestock, land and household. They sometimes lack ownership rights, control over resources and may or may not have control over the animals. However, in some societies, women are responsible only for processing livestock products. In many societies, women are responsible for managing and processing smallstock and other animals kept at the homestead. They are the backbone of the pastoral economic structure in Tripura's, a state in India, as the production system is much dependent on them. In spite of substantial participation and contribution to pastoral economy, the role of women in Tripura livestock production has not been paid enough attention. The status of the pastoral tribal women of Tripura has not remained static over time and is undergoing rapid changes at present. Their status is looked at from various angles, both in the past and at present, in the book entitled "Status of Tribal Women in Tripura".

Tripura is a hilly state in the north-eastern region of India (Figure 1) and lies in five mountain ranges - Boromura, Atharamura, Longtharai, Shakhan and Jampui hills - in a north to south direction. Due to its geographical isolation, economic progress in Tripura state is hindered and poverty and unemployment continue. Most residents are involved in agriculture and allied activities, although the service sector is the largest contributor to the state's gross domestic product (GDP). The population of Tripura is about three million, of

\footnotetext{
* Correspondence: thjaweed@gmail.com

'Department of Environmental Sciences, Government College Larnoo, Anantnag Kashmir 192202, India

Full list of author information is available at the end of the article
}

whom one third are tribal people. Altogether, there are 19 tribes in the State. These are Tripuri, Reang, Jamatia, Noatia, Lusai, Uchai, Chaimal, Halam, Kukis, Garos, Mog and Chakma which belong to the settled tribal community of Tripura. Other tribes like Bill, Munda, Orang, Santal, Lepcha, Khasia and Bhutias are recent immigrant tribes settled here for economic reasons.

Tripura has rich forest resources. Some tribes practice shifting cultivation $\left(j h u m^{a}\right)$ and are accustomed to forest life. Nomadic tribes including the Bill, Munda, Orang, Santal, Lepcha, Khasia and Bhutias practice transhumance, moving seasonally between winter and summer pastures. They keep cattle, sheep and goats for grazing in the hilly and mountainous areas. However, tribes like Tripuri, Reang, Jamatia, Noatia, Lusai, Uchai, Chaimal, Halam, Kukis, Garos, Mog and Chakma have subsistence strategies which combine crop agriculture, horticulture, livestock and fish farming.

The book is a collection of eight chapters on various dimensions. It has an introductory chapter that explains the subject matter, followed by detailed studies by eminent scholars of Tripura on various aspects such as laws, customs, economic role, status, risks, gender dimension and stages of tribal economy.

The introductory chapter discusses the analysis of women in tribal societies with special reference to their condition, social position and community leadership. A comparison is made between tribal societies with that of non-tribal societies. In general, it has been inferred that women in tribal societies enjoy a higher status than their non-tribal counterparts or even their own menfolk, mainly because 


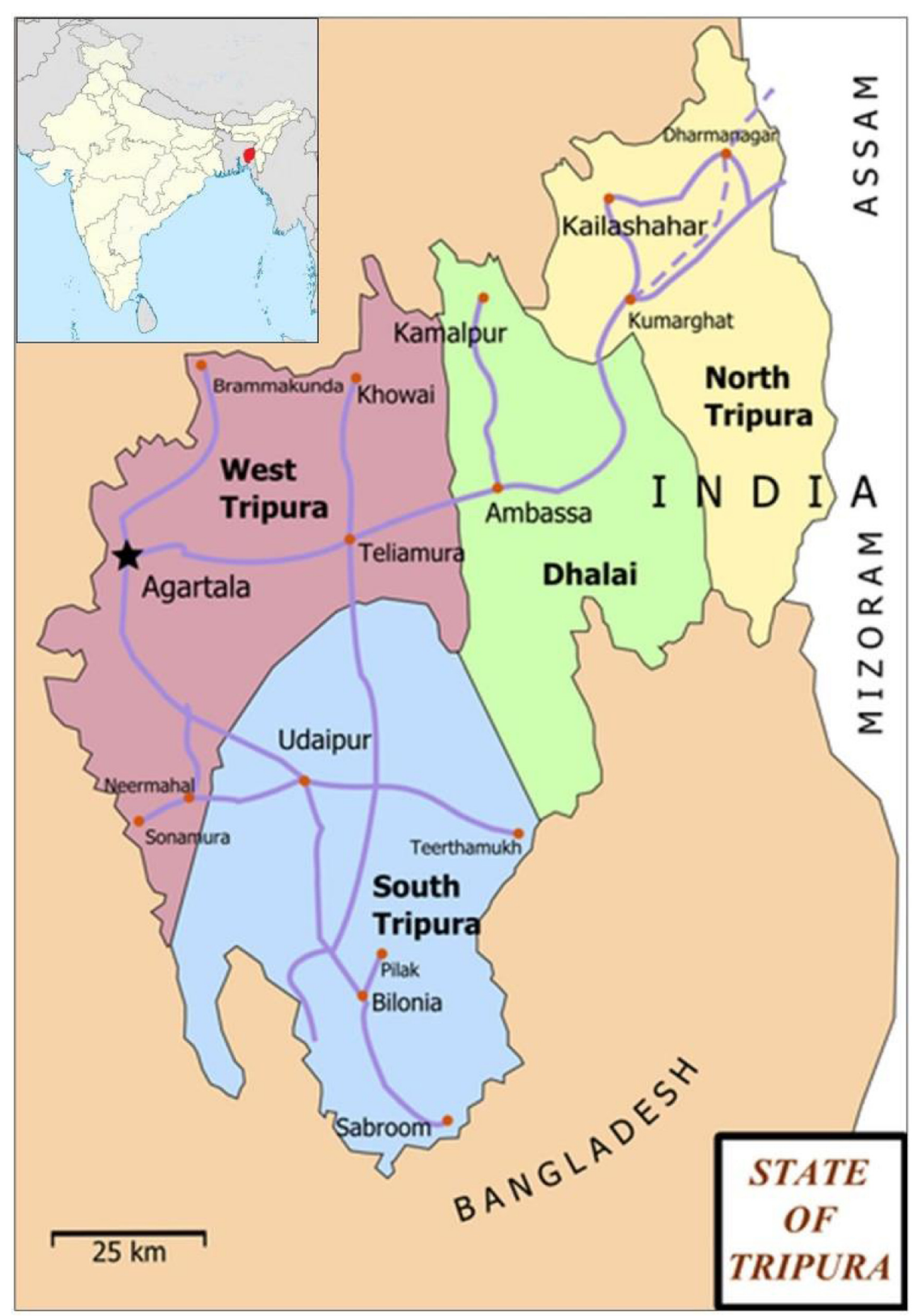

Figure 1 Location of Tripura in India. 
of the leading role they play in production. They enjoy considerable freedom in sex and in choice of their husband.

The Status of tribal women in the customary laws of Tripura by Manik Chakraborty highlights the legal ways in which the status of tribal women in Tripura has been empowered from its deplorable state, after the Hindu Succession Act, 1956. This act was introduced as a step in the practical recognition of equality of the sexes, meant to elevate women from a subservient position in the economic field to a higher level where they could exercise full powers of enjoyment and disposal of property. As per the provisions of this act, now a daughter has equal rights for inheritance of property as her brother.

Dipak Kumar Chaudhri explains the practice of sati among the tribal societies of Tripura -a custom of burning a widow at the funeral pyre of her husband. The tribal societies of India were never affected by this custom, as their marriage institutions were always relatively liberal, where widow remarriage had never been a social offense.

The economic role and status of tribal women in Tripura is comprehensively discussed by Tapati Chakraborty and Pratab Choudhury in two successive chapters. They highlight that there is a decline in the tribal women's traditional activities. A significant proportion of the female cultivators (agro-pastoralists) and cottage industry workers have joined the force of agricultural labourers. Their contribution in agriculture and allied sectors has increased considerably, and thus, the occupational pattern of tribal women has shifted from pastoralists to agricultural labourers. This economic participation does have a role in maintaining the status of tribal women in their society and their enjoyment of high esteem.

Malbika Das Gupta deals with the institution of bride price among the tribal groups of Tripura, treating the prevalence of this custom as an indicator of the high status enjoyed by tribal women in the state. However, it is not merely the continuing economic and non-economic value of women of their upkeep which explains the prevalence of bride price among the tribal peoples of Tripura. Demographic and sociological factors are of equal importance in explaining this phenomenon. Thus, the status of women in tribal society is determined by causes related to the economic functions of women.

The nutritional case study on women in Tripura is discussed jointly by Debnath and Sircar who show that low dietary intake eventually affects the stature of both males and females, but when females are affected, they are justifiably classified as 'at risk women'. The authors are of the opinion that malnourishment in the girl's childhood leads to stunted growth among women in their adulthood, particularly deformity of the pelvic girdle, which may be responsible for the mal-development of the fetus and has been scientifically established through experiments on X-ray pelvimetry. Such results are found from tribal women of
Tripura. However, this is found with non-tribal counterparts as well and must not be related with the status of tribal women.

In the chapter on Adding gender dimension to tribal studies, the author R. Bhattacharjee remarks that conventional concepts among social scientists, especially economists, have always led to under-assessment of the useful work done by women. It is known that the very exclusion of domestic work from the purview of national income has created a great gap in the estimation of the contribution of women to an economy. Furthermore, it is aptly underlined that the status of women in tribal societies is much better than that of women in non-tribal societies so far as the gender equation is concerned.

The Status of tribal women in economy of Tripura is discussed by J.B. Ganguly who finds that the women's status has improved in making business transactions with traders, in selling their own products etc. The women are becoming more and more involved in the decision-making process. They show better appreciation of the need for conservation of forests and water resources, since they are more directly concerned with the collection of firewood and other minor forest products, as well as fetching water for meeting daily needs. The women are pragmatic, hardworking and even forward-looking. It is a fact that no village development plan can be prepared and implemented without the active involvement of the women.

However, with the spread of development, the tribal groups have come under the influence of cultural and socioeconomic patterns of high-caste Hindu groups, thus losing their own tribal identity and thereby contributing to tribal women's loss of status. The large-scale exodus of tribal men to urban areas in search of a living has imposed a double burden on women left behind, forcing them to fend for themselves and their families and even work in the fields, thus further deteriorating women's condition.

Overall, this book is a valuable resource for general students of pastoralism and especially for academic researchers in this field. The detailed case studies are likely to be of more interest to the former.

\section{Endnote}

${ }^{a}$ Tribal groups in the areas where rainfall is more than $1,000 \mathrm{~mm} /$ year generally practice shifting cultivation (jhuming) in the hilly and mountainous areas.

\section{Competing interests}

The authors declare that they have no competing interests.

\section{Author details}

'Department of Environmental Sciences, Government College Larnoo, Anantnag Kashmir 192202, India. Women's Study Centre, University of Kashmir, University Campus Hazratbal, Srinagar 190006, India.

Received: 7 January 2015 Accepted: 27 January 2015

Published online: 12 March 2015 